\title{
The Connotation of Work Values: A Preliminary Review
}

\author{
Ying Liu (Corresponding author) \\ Faculty of Education Science, Sichuan Normal University, Chengdu 610101, China \\ E-mail: tianya516888@yahoo.com.cn \\ Yong Lei \\ Faculty of Education Science, Sichuan Normal University, Chengdu 610101, China \\ Tel: 86-28-8199-7673 E-mail: leiyong214@gmail.com
}

Received: June 18, 2011

doi:10.5539/ass.v8n1p47
Accepted: August 5, $2011 \quad$ Published: January 1, 2012

URL: http://dx.doi.org/10.5539/ass.v8n1p47

\begin{abstract}
This paper first takes the method of literature review, generalizes the consensus of values' definitions: concept or belief of action; a kind of attitudes, tendencies, or beliefs; cognitive representations of human requirement; comprehensive definitions. It also briefly generalizes the mainstream views of values' structures. Then, it argues that work values can be defined from three perspectives, the $1^{\text {st }}$ of which is the perspective of tendency or orientation of beliefs or attitudes as following: tendency of career choice and commitment of learning and work, beliefs about the desirability of various work features, constellations of attitudes and opinions, anticipation about results of occupational work, and representing motivational aspects; the $2^{\text {nd }}$ of which is the perspective of estimation as: assessment of the importance of a goal or behavior, the importance individuals give to the outcomes arising in the work context, standards of evaluation, and information system of estimation; and the $3^{\text {rd }}$ of which, the perspective of synthesis as relatively overall generalization of work values. At last, it briefly generalizes the structures of work values from different dimensions.
\end{abstract}

Keywords: Values, Structure of values, Work values, Structure of work values

\section{Introduction}

An individual's career choice may be strongly influenced by the values that he or she holds. Recent study provides evidence for the importance of values in individual's choosing of careers. For example, individuals tend to choose jobs that have similar value contents to their own value orientations (Judge \& Bretz, 1992). In addition, some evidences show that the ordering of values has an important influence on occupational preference (Cochran, 1986). Specifically, individuals organize their decision-making schemes for occupations according to a hierarchy of values. In career counseling, values are often useful to clients who are deciding upon a career direction (Sharf, 1992). Counselors might ask clients to conceptualize, list, and classify their values or to fill out a values inventory to measure the relevant performance of various values for particular client (Sharf.1992). Overall, it seems that values have an immense influence on individuals' career preferences and choices and are important in career counseling (Judge \& Bretz, 1992; Sharf,1992).

Numerous studies have discussed the connotation of values and work values. Unfortunately, the discussions are either superficially or respectively limited as to the arguing some aspects of connotation or implementing empirical study with some concepts of relevant work value. Hence, there have no systematical connotation discussions of work values in existence. This paper will systematically review the literal definition of work values. It then offers a review of the structural foundations of work values. Before proceeding to review the definition of work values, it is necessary to give some initial attention to the meaning of values.

\section{The definitions of values}

\subsection{As the concept of action or belief of action}

There are various discussions on human values about its literal meaning. Perhaps the most influential definition of values traces back to Kluckhohn (1951): "A value is a conception, explicit or implicit, distinctive of an individual or characteristic of a group, of the desirable, which influences the selection from available modes, 
means, and ends of action." Lesthaeghe and Moors (2000) argue that Kluckhohn takes a functionalist, deterministic view in which values are cultural imperatives that necessarily lead to certain actions. Rokeach (1973) defines value as "an enduring belief that a specific mode of conduct or end-state of existence is personally or socially preferable to an opposition or converse mode of conduct or end-state of existence". In other words, a value is an internalized standard for one's own and others' behavior. While Kluckhohn emphasizes action, Rokeach thinks values as giving meaning to action. Values are generalized and relatively abstract superseding evaluative standards that define desirable ends and ways to achieve them (Olson \& Zanna, 1993). An individual does not fully "reach" or achieve a value such as the value of fairness, for example. Fairness "guides" the evaluation of prospective actions and events and allows an individual to define and give meaning to work experiences (Lewin, 1951).

\subsection{As attitudes, tendencies, or beliefs}

Locke (1976) considers that a value is what one regards as conducive to one's welfare. Levy and Guttman (1976) consider values are a subset of attitudes with a special emphasis on the concept of importance. According to Levy and Guttman, an item belongs to the universe of value items if, and only if, its domain asks estimation of the degree of importance of a goal or behavior in life area and the range is ordered from very important to obtain to very important to avoid the goal. Hofstede (1980) defines value as "a broad tendency to prefer certain states of affairs over others". According to Schwartz and Bilsky (1987), values can be defined as concepts or beliefs about desirable end states or behaviors that transcend specific situations, guide the selection or evaluation of behavior and events, and are ordered by their relative importance. Values are "evaluative beliefs that synthesize affective and cognitive elements to orient people to the world in which they live" (Marini, 1984).

\subsection{As cognitive representations of human requirement}

Schwartz (1992) emphasizes that values are cognitive representations of three universal human requirements: (a) biologically based organism needs, (b) social interactional requirements for interpersonal coordination, and (c) social institutional demands for group welfare and survival.

\subsection{As synthesis}

Huang et al. (1994) argues that values "are the conceptual systems of people distinguishing good or bad, beautiful or ugly, true or false, conforming or violating own wish, usually filling emotion, and supplying full argument for proper behavior".

\section{The values' structures}

Structure of values is as "an enduring organization of beliefs concerning preferable modes of conduct or end-states of existence along a continuum of relative importance" (Rokeach, 1973). Rokeach's structure has two dimensions of values: terminal values and instrumental values. He reports that terminal values can be illustrated through nine values: (1) international harmony and equality: a good life for others, rule by the people, international cooperation, social progress and social reform, a world at peace, a world of beauty, human dignity, equal opportunity, greater economic equality, and preserving the natural environment; (2) personal growth and inner harmony: self-knowledge or self insight, the pursuit of knowledge, inner harmony, self-improvement, wisdom, and self-respect; (3) secure and satisfying interpersonal relationships: mature love, true friendship, personal support, security for loved ones, and acceptance by others; (4) social standing: recognition by the community, economic prosperity, and authority; (5) national strength and order: national greatness, national economic development, the rule of law, and national security; (6) traditional religiosity: salvation, religious or mystical experience, upholding traditional sexual moral standards, and sexual intimacy; (7) social stimulation: an active social life and an exciting life; (8) physical well-being: physical development, good health, and physical exercise; and (9) individual rights and basic necessities: privacy for yourself, a sense of ownership, a leisurely life, carefree enjoyment, the protection of human life, comfort but not luxury. He reports that instrumental values can be illustrated through ten values: (1) a positive orientation to others: tolerant, helpful, forgiving, giving others a fair go, tactful, considerate, cooperative, loving, trusting, grateful, understanding, friendly, and generous; (2) competence and effectiveness: bright, adaptable, competent, resourceful, self-disciplined, efficient, knowledgeable, persevering, progressive, conscientious, logical, and showing foresight; (3) propriety in dress and manners: polite, patriotic, prompt, refined, clean, neat, and reliable; (4) religious commitment: committed, devout, self-sacrificing, and idealistic; (5) assertiveness: standing up for your beliefs, having your say, and determined; (6) withdrawal from others: keeping to yourself and independent; (7) carefreeness: acting on impulse, spontaneous, and cautious; (8) honesty: open and honest; (9) thriftiness: thrifty and never missing a chance; (10) getting ahead: ambitious and competitive. Pokeach relatively completely defines the values. His hierarchical model is successful in covering many and various facets of the value realm. However, some of his 
listed items do not pass the examination of inheritors (e.g., Braithwaite \& law (1985), who considers that the items of thriftiness and carefreeness do not have representativeness).

Schwartz (1994) has built a sketchy representation of what he finds to be an almost universal structure of human values. Schwartz's framework has two higher-order dimensions of values: openness to change versus conservation, and self-enhancement versus self-transcendence. The structure is not a perfect representation, but it is "a reasonable approximation of the structure of relations among the ten value types in the vast majority of samples" (Schwartz, 1994). He reports that the following ten values, each defined in terms of its motivational goal, are recognized in approximately 70 cultures around the world: (1) hedonism: self-centered sensual gratification; (2) power: status and prestige, control people and resources; (3) achievement: competitive personal success; (4) stimulation: encourage risk taking and adventure; (5) self-direction: autonomous thought and action (idea of agency); (6) universalism: tolerance and concern for welfare of all others; (7) benevolence: preserve and enhance welfare of those with whom one is in frequent personal contact; (8) conformity: self-restraint and subordination of one's own inclinations to the expectations of others; (9) tradition: traditional and religious activities; and (10) security: stability, safety, and harmony of society, relationships, and self.

Schwartz (1994) further defines value as desirable trans-situational goals, varying in importance, that serve as guiding principles in the life of a person or other social entity. Implication of Schwartz's definition of values as goals is that:

. they serve the interests of some social entity;

. they can motivate action - giving it direction and emotional intensity;

. they function as standards for judging and justifying action; and

. they are acquired both through socialization to dominant group values and through the unique learning experience of individuals.

\section{The definitions of work values}

\subsection{From the perspective of tendency or orientation of beliefs or attitudes}

Work values, or the goals that one seeks from working, play a crucial role in an individual's life and career development (Rosenberg, 1957; Super, 1990). They affect educational and career choices, and one's commitment to learning and work. People tend to select careers that are consistent with their work values; otherwise, they change their work values in the direction of the dominant values of their chosen fields of work (Rosenberg, 1957; Super, 1990). Monica (2005) considers that work values are beliefs about the desirability of various work features and are usually applied by referencing potential rewards derive from working (e.g., pay, prestige, opportunities to learn). Brown (1996) defines work values as the values that individuals believe should be satisfied as a result of their occupational work. According to Pennings (1970), work-value systems can be defined as constellations of attitudes and opinions with which individuals evaluate their jobs and work environments. Herzberg et al. (1959) considers work values as representing motivational aspects, i.e. motivators and hygiene.

\subsection{From the perspective of estimation}

In terms of Levy's and Guttman's (1976) definition of values, an item is subject to the universe of work values if its domain asks for an assessment of the importance of a goal or behavior in the work context and the range is ordered from very important to very unimportant. A work value can be defined as the importance individuals give to outcomes arising in the work context (Elizur, 1984). Work-related values refer to the goals or rewards people seek through their work, and they are expressions of more general human values in the context of the work setting (Schwartz, 1999). Work values are a kind of evaluation of persons for requirements of social career (huang et al., 1994). Work values are the standards of individual evaluation and vocational choice (jin \& li, 2005). Liu and Zhao (2001) define work values as one person's evaluations and viewpoints about meaning and importance to related objective thing. Yu and $\mathrm{Li}$ (2003) consider work values are an information system with stability, generalization, and dynamic functions which are in terms of the needs of people for work, work behavior, and work results; are reflected general values in career life, are the estimation for social and vocational needs by individuals.

\subsection{From the perspective of synthesis}

Work values represent the beliefs and attitudes of persons for occupation, are a type of value orientation in career life, and are values' exemplification on vocational choice. Vocational values are shown relatively stable, generally and dynamically functional system of concept, reflected general values on vocational choice, impact 
career choice and vocational development in future (wang, 2009). Work values are values' exemplification on vocational choice (lin et al., 1999). Work values are an information system with stability, generalization, and dynamic functions, which are based on the needs of people for work, work behavior, and work results; which reflect general values in career life, decide not only tendency of career choice but also work attitudes; and they are the crystallization which derives from long-term social change about work experience and feeling by individuals; it is subject to the category of personality tendencies (Yu et al., 2001). Super (1971) defines work values as the part of individuals' values that work can satisfy. According to Super (1971), values derive from needs are more general than interests, work values are goals that one seeks to attain to satisfy a need; they may be satisfied by more than one kind of activity or occupation. Further, Connor and Becker (1975) have proposed that values have implications for conflict, communication, organizational performance, and managerial actions, such as emphasis on goals and types of control.

\section{The structures of work values}

\subsection{Dichotomy}

Herzberg (1966) considers work values should be divided as intrinsic and extrinsic ones, which are two unrelated concepts. He terms them "motivators" and "hygiene" factors, respectively. Intrinsic work values are defined as those inherent in an activity (Nevill \& Super, 1989). For example, individuals can choose to teach young children because they believe that the happiness of children is important. Extrinsic work values are values that are outcomes of the activity (Nevill \& Super, 1989). Extrinsic individuals can choose to open an Internet-based company because they value money and status. Both types of values can be assessed during the career counseling process and can be used to help the client through the self-exploration process (Nevill \& Super, 1989). The term extrinsic work values refers to values concerning the outcome or external factors of work, whereas the term intrinsic work values refers to the actual content of work (George \& Jones, 1997). Rokeach (1973) divides work values into two dimensions: work values with instrumentalism; work values with end-state. Most research on work values has differentiated values with reference to two broad types of rewards derive from working. Intrinsic rewards of work refer to gratifications derive from the work tasks themselves (e.g., interest, challenge, responsibility); extrinsic rewards are obtained from the job but are external to the task experience (e.g., pay, security, and prestige), extrinsic rewards are sometimes characterized as instrumental-the means to achieve non-work goals. Extrinsic and intrinsic values are not opposite ends of a continuum but rather two dimensions of work values that are usually somewhat positively correlated in empirical studies (Monica, 2005).

\subsection{Trichotomy}

Researches on work values can be divided into three main streams: structure, correlation to other personal, social, or organizational variables, and cultural factors (Sagie et al., 1996). Super (1957) considers work values should be divided into three types: intrinsic value, extrinsic value, and extrinsic rewards. Alderfer (1972) proposes a relative comprehensive and concise sub-division method of work values on the basis of Super's classification, which are divided into three types: intrinsic value, extrinsic value, and social value. Elizur (1984) arrived at a related trichotomous classification of work values by considering the modality of their outcomes: instrumental outcomes such as work conditions and benefits; cognitive outcomes such as interest and achievement; affective outcomes such as relations with associates. Lin et al. (1999) systematically investigates work values of college students. He concludes that work values include three factors: development, prestige, and hygiene. Yu and Huang (2000) argue that work values should be classified as intrinsic value, extrinsic value, and rewards. Ni and $\mathrm{Ma}$ (2000) elicit the factors of work values: organizational environment, job estimation, personal requirements.

\subsection{Four-dimensional perspective}

Schwartz (1999) divides work values into four broad types, intrinsic, extrinsic, social, and power, and he defines them as: (1) intrinsic: personal growth, autonomy, interest, and creativity; (2) extrinsic: pay and security; (3) social: contact with people and contribution to society; and (4) power: prestige, authority, and influence. Rone (1994) divides work values into four types: (1) individual-centered and self-actualization of humanism; (2) collectivism-centered and community of humanism; (3) individual-centered and self-esteem of materialism; and (4) collectivism-centered physical security of materialism; which derive from a cross-cultural research among work values of seven countries, the outcomes are accordance with Maslow's, McClelland's, Herzberg's viewpoints. Zhao (1984) divides work values into four types: preference, social interests, comfort of prestige, and economy.

\subsection{Five-dimensional perspective}

Jaw (2007) views that the concept of work values was defined in terms of five domains: (1) Self-enhancement; 
(2) contribution to society; (3) stability and rewards; (4) openness to change; and (5) power and status. He defines them as follows: (1) "Self-enhancement" is a measure of one's desire to reach his/her full potential by becoming everything one is capable of becoming (Maslow, 1943, 1959). It comes under intrinsic work values (Schwartz, 1999), which concerns Maslow's $(1943,1959)$ self-actualization and esteem needs, Herzberg et al.'s (1959) motivators, Schwartz's (1999) intrinsic needs, and McClelland's (1987) achievement motive. (2) "Contribution to society" stresses the degree that a job helps improving the wellbeing of a society in the employee's point-of-view (Schwartz, 1999). It is related to Maslow's $(1943,1959)$ social needs and Schwartz's (1999) social work values. (3) "Stability and rewards" refers to monetary stability such as pay, job security, and uncertainty avoidance such as clear job descriptions in an organizational setting (Maslow, 1943, 1959; Hertzberg, 1959; Schwartz, 1999). It comes under the extrinsic work values (Schwartz, 1999), and it relates to Maslow's (1943, 1959) security needs, Herzberg et al.'s (1959) hygiene factors, and Schwartz' (1999) extrinsic needs. (4) "Openness to change" measures the degree to which employees perceive that a job merits meaning, emotional interest, intellectual interest and creativity (Hertzberg, 1959; Schwartz, 1999). It also comes under the intrinsic work values (Schwartz, 1999). (5) "Power and status" measures the extent to which employees perceives a job brings prestige/self-esteem, authority, influence and control, and respect from others (Maslow, 1943, 1959; Schwartz, 1999; McClelland, 1963). Ning (1991) elicits five factors of work values: enterprise, lifestyle, job stability, prestige, economic value.

\subsection{Multidimensional perspective}

O'connor and kinnane (1961) divide work values into six dimensions: security-economical-material, social-artistic, work conditions and associates, heuristic-creative, achievement-prestige, and independence-variety. Liu and Zhao (2001) develop an empirical study, which divides work values into 10 types: independence, advanced study, promotion, putting knowledge into practice, environment, treatment, colleagues, welfare, working hours, and leisure. Hu et al. (2001) divides work values into eight aspects: individual development, social development, unit's development, interpersonal relationship, economic rewards, achievement-prestige, environment, and the influence of family. Wang and Liao (2003) divide work values into six types: interpersonal relationship, self-development, contribution, prestige, household, and material life.

\section{Conclusions}

Work values are based on human values which provide the epistemological and methodological basement. Before proceeding to review the definition of work values, it is necessary to give some initial attention to the meaning of values. Researchers offer definitions from the perspective: (1) as the concept of action or belief of action (Kluckhohn, 1951; Lewin, 1951; Rokeach, 1973; Olson \& Zanna, 1993; Lesthaeghe \& Moors, 2000); (2) as attitudes, tendencies, or beliefs (Locke ,1976; Levy \& Guttman, 1976; Hofstede, 1980; Schwartz \& Bilsky, 1987; Marini, 1984); (3) as cognitive representations of human requirement (Schwartz, 1992); (4) as synthesis (Schwartz, 1994; Huang et al., 1994); respectively state the definition of values. Some researchers further analyze the structures of the values (e.g., Rokeach, 1973; Schwartz, 1994).

Work values can be defined from the perspective of tendency or orientation of beliefs or attitudes as: tendency of career choice and commitment of learning and work (Rosenberg, 1957; Super, 1990), beliefs about the desirability of various work features, constellations of attitudes and opinions (Pennings, 1970), result's anticipation of occupational work (Brown, 1996), representing motivational aspects (Herzberg et al., 1959). It can also be defined from the perspective of estimation as: assessment of the importance of a goal or behavior (Levy and Guttman, 1976), the importance individuals give to outcomes arising in the work context (Elizur, 1984), standards of evaluation and information system of estimation (huang et al., 1994; jin \& li, 2005, Liu \& Zhao, 2001; Yu \& Li, 2003). And it can be defined from the perspective of synthesis as relatively overall generalization (Super, 1971; Connor and Becker, 1975; lin et al., 1999; Yu et al., 2001; wang, 2009;). Furthermore, researchers analyze the structures of work values from: two-dimensional, three-dimensional, four-dimensional, five-dimensional, and multidimensional.

In the past 30 years, many literatures have focused on researches of the work values. However, most of these were stranded on the facet of empirical research. They did not discuss it in depth or theoretically analyze the connotation of work values. Limited theoretical research did not systematically generalize the connotation of work values. Most of the literatures inherited and assimilated the Herzberg's and super's thesis. Furthermore, some researchers have brought this epistemology and methodology into practice to solve and illustrate relevant problems, and applied or developed it to explore the work values in various fields. However, more and more relevant researches have extended the space of work values, though mainly based on psychological theories. They lacked the vision of philosophy in the studies of work values. Few studies have noted the ontological, 
essential, and axiological facets of work values. Therefore, further studies may be focused on the following fields: What is the ontological basement of work values? How is the relationship between the ontological values and axiological values? What are the future trends of work values?

\section{References}

Alderfer, C. P. (1972). Existence, relatedness and growth: Human needs in organizational settings. New York: Free Press.

Braithwaite, V. A. \& Law, H. G. (1985). Structure of human values: testing the adequacy of the Rokeach value survey. Journal of Personality and Social Psychology, 40(1), 250-263. http://dx.doi.org/10.1037/0022-3514.49.1.250

Brown, D. (1996). Brown's values-based, holistic model of career and life-role choices and satisfaction. In D. Brown \& L. Brooks (Eds.), Career Choice and Development (pp. 337-372). San Francisco, CA: Jossey-Bass.

Cochran, L. R. (1986). Harmonious values as a basis for occupational preference. Journal of Vocational Behavior, 29, 17-26. http://dx.doi.org/10.1016/0001-8791(86)90026-6

Connor, P. E. \& Becker, B. W. (1975). Values and the organization: Suggestions for research. Academy of Management Journal, 18, 550-561. http://dx.doi.org/10.2307/255684

Elizur, D. (1984). Facets of work values: A structural analysis of work outcomes. Journal of Applied Psychology, 69, 379-389. http://dx.doi.org/10.1037/0021-9010.69.3.379

George, J. \& Jones, G. (1997). Experiencing work: Values, attitudes, and moods. Human Relations, 50, 393-416. http://dx.doi.org/10.1177/001872679705000404

Herzberg, F., Mausner, B. \& Snyderman, B. (1959). The motivation to work. New York: Harper.

Hofstede, G. (1980a). Cultural consequences: International differences in work-related values. Sage, CA: Newbury Park.

Hu, X. Y., Lian, R. \& Shao, Y. L. (2001). On the professional vales of teaching of the Students in normal universities (in Chinese). Journal of Jimei University, 2(3), 45-48.

Huang, X. T., Zhang, J. P. \& Li, H. (1994). Value and education of Chinese contemporary youth (in Chinese). Chengdu: Sichuan Education Publishing House.

Jaw, B. S., Ling, Y. H., Wang, Y. P. \& Chang, W. C. (2006). The impact of culture on Chinese employees' work values. [Online] Available: www.emeraldinsight.com

Jin, S. h. \& Li, X. (2005). The structure of college students work values: Intentions and instruments (in Chinese). Acta Psychologica Sinica, 37(5), 650-657.

Judge, T. A. \& Bretz, R. D., Jr. (1992). Effects of work values on job choice decisions. Journal of Applied Psychology, 77, 261-271. http://dx.doi.org/10.1037/0021-9010.77.3.261

Kluckhohn, C. (1951). Values and value-orientations in the theory of action. Toward a General Theory of Action (pp. 388-433), ed. T Parsons, EA Shils. New York: Harper.

Lesthaeghe R. \& Moors G. (2000). Life course transitions and value orientations: Selection and adaption. Presented at contact forum: Values Orientations and Life Cycle Decisions, Results from Longitudinal Studies, Brussels.

Levy, S. \& Guttman, L. (1976). Values and attitudes of Israeli high school children. The Israel Institute of Applied Social Research, Jerusalem (Hebrew translation).

Lewin, I.C. (1976). Field theory in social science. New York: Harper.

Liu, G. Z., \& Zhao, S. P. (2001). Study and application of vocational value (in Chinese). Journal of Qindao Institute of Chemical Technology (Social Sciences), 56(1), 47-49.

Locke, E. A. (1976). The nature and causes of job satisfaction. In M. D. Dunnette (Ed.), Handbook of industrial and organizational psychology (pp. 1297-349). Chicago: Rand McNally.

Marini, M. M. (1984). Age and Sequencing Norms in the Transition to Adulthood. Social Forces, 63, 229-244.

Maslow, A. (1943). A theory of human motivation. Psychological Review, 50, 370-396. http://dx.doi.org/10.1037/h0054346

Maslow, A. (1959). Motivation and personality. New York: Harper \& Row. 
McClelland, D. C. (1963). The achieving society. New York: Van Nostrand Press.

Monica, k. j. (2005). Family roles and work values: Processes of selection and change. Journal of Marriage and Family, 67(2), 352-369. http://dx.doi.org/10.1111/j.0022-2445.2005.00121.x

Nevill, D. D. \& Super, D. E. (1989). The values scale: Theory, application, and research (2nd ed.). Palo Alto, CA: Consulting Psychologists Press.

Ni, C. M. \& Ma, J. H. (2000). Analysis the relationship between work values and organizational conduct for employees of enterprises (in Chinese). Ergonomics, 6(4), 24-28.

Ning, W. W. (1991). A summary on work value studies (in Chinese). Studies of Social Psychology, 2, 34-40.

O'connor, J. P. \& Kinnane, J. F. (1961). A factor analysis of work values. Journal of Counseling Psychology, 8(3), 263-267. http://dx.doi.org/10.1037/h0047440

Olson, J. M. \& Zanna, M. P. (1993). Attitudes and attitude change. Annual Review of Psychology, 44, 117-54. http://dx.doi.org/10.1146/annurev.ps.44.020193.001001

Pennings, I. M. (1970). Work value systems of white-collar workers. Administrative Science Quarterly, 15, 397-405. http://dx.doi.org/10.2307/2391330

Rokeach, M. (1973). The nature of human values. New York: Free Press.

Rosenberg, M. (1957). Occupations and values. Glencoe, IL: The Free Press.

Sagie, A., Elizur, D. \& Yamauchi, H. (1996). The structure and strength of achievement motivation: A cross cultural comparison. Journal of Organizational Behavior, $17,431$. http://dx.doi.org/10.1002/(SICI)1099-1379(199609)17:5<431::AID-JOB771>3.0.CO;2-X

Schwartz, S. H. \& Bilsky, W. (1987). Toward a psychological structure of human values. Journal of Personality and Social Psychology, 53, 550-62. http://dx.doi.org/10.1037/0022-3514.53.3.550

Schwartz, S. H. (1992). Universals in the content and structure of values: theoretical advances and empirical tests in 20 countries. Advances in Experimental Social Psychology (pp. 1-65), ed. Zanna, M. P. San Diego, CA: Academic.

Schwartz, S. H. (1994). Are there universal aspects in the structure and content of human values? Journal of Social Issues, 50, 19-45. http://dx.doi.org/10.1111/j.1540-4560.1994.tb01196.x

Schwartz, S. H. (1999). A theory of cultural values and some implications for work. Applied Psychology: An Introductional Review, 48 (1), 23-47. http://dx.doi.org/10.1111/j.1464-0597.1999.tb00047.x

Sharf, R. S. (1992). Applying career development theory to counseling. Pacific Grove, CA: Brooks/Cole.

Super, D. E. \& Super, C. (1957). The psychology of careers. New York: Harper.

Super, D. E. (1971). Work values inventory. Boston: Houghton Mifflin.

Super, D. E. (1990). A life-span, life-space approach to career development. In D.Brown and L. Brooks (eds.), Career Choice and Development. San Francisco: Jossey-Bass.

Wang, L. X. \& Liao, B. (2003). Survey on vocational values of normal university students (in Chinese). Journal of Nanjing Normal University (Social Science Edition), 5, 100-105.

Wang, X. T. (2009). Empirical research on college students' work values (in Chinese). Education Review, 1, 78-80.

Yu, H. P., Zhang, D. J. \& Zhang, J. F. (2001). Primary Conformation of Occupational Values of Normal University Students (in Chinese). Journal of Southwest China Normal University, 27(2), 61-66.

Yu, H. \& Huang, X. T. (2000). Comparative Study on Work Values between College Students and Mainland Employees (in Chinese). Psychological Science, 23(6), 739-740.

$\mathrm{Yu}, \mathrm{Y}$. H. \& Li, Z. (2003). Research on the feature of work values and educational countermeasure for contemporary college students (in Chinese). Education Exploration, 12, 42-44.

Zhao, X. S. (1984). Research on guidance of youth work values (in Chinese). Youth research, 3, 24. 